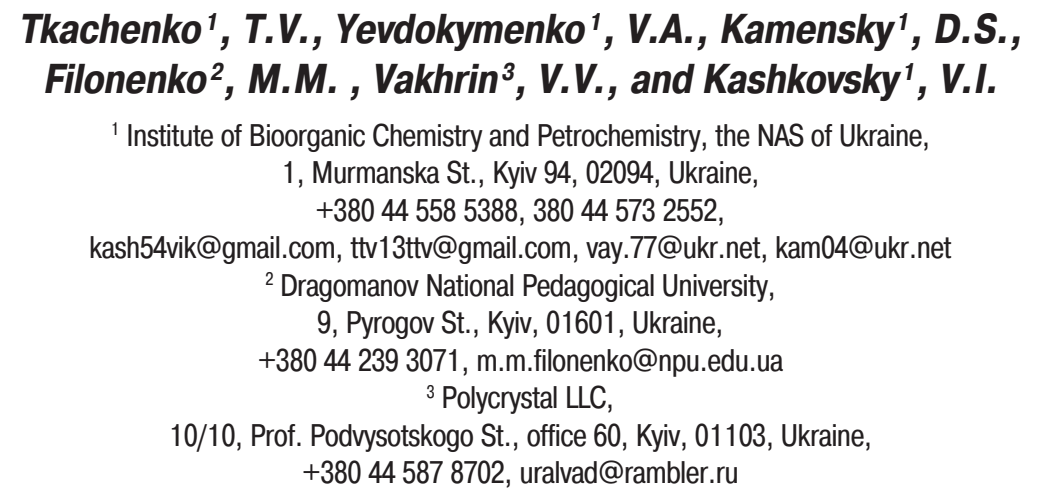

\title{
PROCESSING OF VEGETABLE WASTE OF DIFFERENT ORIGIN
}

Introduction. Biomass is primarily used as energy source, however, it is a valuable chemical raw material. As of today, there are about 20 basic compounds that are sufficient to provide a wide range of chemical products can be obtained from vegetable raw materials.

Problem Statement. Despite a huge capacity of vegetable waste recycling for the industrial needs, so far research in this area has received a little attention in Ukraine.

Purpose. To create an effective technological solution that ensures a comprehensive, waste-free processing of vegetable waste to produce marketable products.

Materials and Methods. The methods of organic solvent pulping, explosion autohydrolysis, heterogeneous catalysis, and numerous analytical techniques (technical, elemental, structural analysis) have been used for the study.

Results. The auto-hydrolysis treatment of plant material has been shown to enable destroying the original compact and strong structure into individual components. For microcrystalline cellulose (MCC), total conversion increases by 6-18\% with a high crystallinity index (Cl) of 0.81. As a result of alkaline treatment of rice husks, the inorganic component has been established to be «extracted» and to decrease in content. This is accompanied by partial delignification and a simultaneous increase in the content of cellulose. Using the method of organic solvent pulping of silica-free husk, the maximum amount of MCC (100\% theoretically possible yield) with a Cl of 0.77 , a polymerization of 560.5 , and a purity of $99.3 \%$ has been extracted. Silicon dioxide with a purity of, at least, 99.99\% has been obtained.

Conclusions. A way for obtaining cellulose from vegetable waste by the organic solvate pulping method has been described and the effect of pretreatment of lignocellulosic biomass on the physical and chemical properties of obtained cellulose has been established.

Keywords: explosion auto-hydrolysis, cellulose, lignin, microcrystalline cellulose, and silicon dioxide.

One of the characteristic features of the present time is the numerous attempts to integrate the plant biomass into the power engineering and raw material sector of the economy [1]. The unpretentiousness of many crops to weather condi-

(C) TKACHENKO, T.V., YEVDOKYMENKO, V.A., KAMENSKY, D.S., FILONENKO, M.M., VAKHRIN, V.V., and KASHKOVSKY, V.I., 2018 tions, broad options for selection, significant energy indices, and a wide range of chemical composition are factors that allow the plant biomass to be considered as a potential source of alternative energy and raw materials. In many world countries, especially in the equatorial zone, plant biomass is currently one of the main sources of energy (that is produced, mostly, by simple com- 
bustion) [1], and in general its share in the energy balance varies from 3 to 35\%. However, global focus on plant energy resources, in our opinion, does not make sense. The development of the raw material direction is much more promising due to a high content of carbohydrates in the form of cellulose, hemicellulose, lignin, pentosans, starch, saccharides, and pectin, which enables a relatively cheap obtainment of a number of highly marketable products widely used in food, medical, perfume, and chemical industries. Every year, the agro-industrial complex produces a significant amount of lignocellulose waste unused or disposed without any pretreatment, which leads to a significant environmental pollution. However, they can be converted into valuable raw materials, in particular, cellulose, mono- and oligosaccharides, and various biologically active substances [2].

Unlike other crops, the rice production waste (straw and floral husk) is known to have a high concentration of silicon that is part of the plant in the phase of full maturity, in the form of amorphous silicon dioxide [2-6]. The rice husk mainly consists of lignin, cellulose, hemicellulose, $\mathrm{SiO}_{2}$, and a small amount of metal oxides [7-10].

The silicon origin in the rice husk has been studied many times, with the majority of researchers believing that silicon is accumulated in the plant as mono-silicic acid that is transported to the outer surface of plant tissue. Here, it concentrates as a result of evaporation and as a result of polymerization transforms into cellulose-siliceous membrane [11].

Due to the lack of nutrients and the negative impact on the health of bovine animals caused by the complexity of digestive processes, the use of husk as a feed, despite its low cost, is not feasible [12].

However, rice husk can be used to obtain a number of organic and inorganic products, including silicon compounds: dioxide, carbide, nitride, tetrachloride, pure silicon, silicates, as well as carbon, xylenes, polysaccharides, furfural, cellulose, etc. [3-5, 13-15]. However, today, in spite of disadvantages, the most common use of rice husk is power generation (combustion).

\section{THE RESULTS AND THEIR DISCUSSION}

The research aim is to create an efficient technological solution that enables integrated almost waste free treatment of residual plant material for obtaining highly marketable products.

Rice husk, corn cob [16], and switchgrass herb (Panicum virgatum L.) [17] are used as raw material for lignocellulose. The chemical composition of studied biomass as determined by the methods described in $[16,17]$ is given in Table 1.

The main distinctive feature of rice husk as compared with other lignocellulosic biomass is a high content of inorganic component. The nondestructive energy-dispersive X-ray fluorescent analysis of rice ash using precise analyzer Expert $3 L$ has shown that main inorganic component is silicon dioxide (Table 2), which agrees with literature data [2-6]. Hence, rice husk unlike corn cob and switchgrass, is a valuable source of not only natural polymers but also amorphous silicon dioxide.

The next stage is separation of raw material into individual components.

Previously, the efficiency of explosion auto-hydrolysis has been proven for separation of corn cob [16] and switchgrass [17] into certain components. Therefore, the products of explosion selfhydrolysis of selected agricultural waste have been

Composition of Original Raw Material

Table 1 for Further Research, \% wt.

\begin{tabular}{|l|c|c|c|}
\hline & Rice husk & $\begin{array}{c}\text { Corn cob } \\
{[16]}\end{array}$ & $\begin{array}{c}\text { Switchgrass } \\
{[17]}\end{array}$ \\
\hline Cellulose & 39.7 & 43.2 & 46.7 \\
Hemicellulose & $13.3^{*}$ & 26.4 & 23.0 \\
Hot water soluble & 8.2 & 4.2 & 7.7 \\
Klason lignin & 20.2 & 23.4 & 13.8 \\
Wax and fats & 0.3 & 0.5 & 2.0 \\
Ash & 18.2 & 1.5 & 5.4 \\
Other & 0.1 & 0.8 & 1.4 \\
Total & 100.0 & 100.0 & 100.0 \\
\hline
\end{tabular}

* Hemicellulose and proteins totally. 


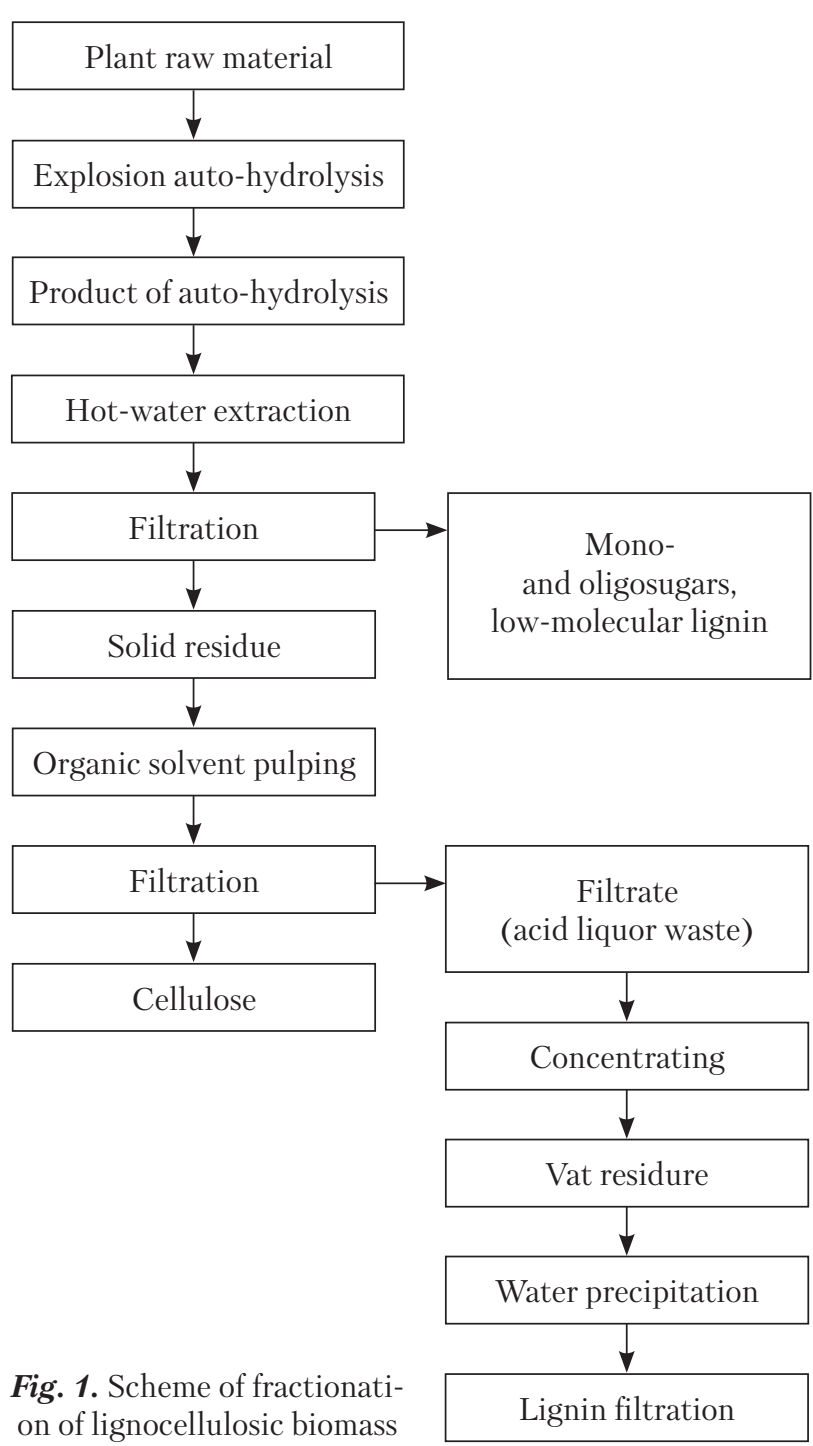

obtained MCC samples were determined by the standard method [20]. MCC polymerization degree was defined based on GOST 9105-74 using a capillary viscometer of VPZh-3 type with a constant velocity of $0.01665 \mathrm{~mm}^{2} / \mathrm{s}^{2}$ in accordance with the method described in [21].

The MCC supramolecular structure was analyzed using diffractometer MiniFlex 300/600 in radiation of copper anode with nickel filter in the initial beam. To carry out $\mathrm{X}$-ray experiments, the studied materials in the form of fine powders were placed in cuvettes having a thickness of

\section{Chemical Composition of Rice Husk Ash}

\begin{tabular}{|c|c|c|c|}
\hline $\begin{array}{c}\text { Chemical } \\
\text { element }\end{array}$ & Content, \% wt. & Substance & Content, \% wt. \\
\hline $\mathrm{O}$ & $51.477 \pm 0.812$ & & \\
$\mathrm{Mg}$ & $2.146 \pm 0.298$ & $\mathrm{MgO}$ & 3.559 \\
$\mathrm{Si}$ & $42.982 \pm 0.719$ & $\mathrm{SiO}_{2}$ & 91.953 \\
$\mathrm{~S}$ & $0.172 \pm 0.006$ & $\mathrm{SO}_{2}$ & 0.344 \\
$\mathrm{~K}$ & $1.944 \pm 0.056$ & $\mathrm{~K}_{2} \mathrm{O}$ & 2.342 \\
$\mathrm{Ca}$ & $1.143 \pm 0.028$ & $\mathrm{CaO}$ & 1.599 \\
$\mathrm{Fe}$ & $0.061 \pm 0.001$ & $\mathrm{Fe}_{2} \mathrm{O}_{3}$ & 0.087 \\
$\mathrm{Cu}$ & $11 \pm 1 \times 10^{-6}$ & $\mathrm{CuO}$ & $14 \times 10^{-6}$ \\
$\mathrm{Zn}$ & $5 \pm 1 \times 10^{-6}$ & $\mathrm{ZnO}$ & $57 \times 10^{-6}$ \\
\hline
\end{tabular}

Composition of Resulting Raw Material

Table 3 after Explosion Auto-Hydrolysis, \%wt.*

fractionated (Table 3) according to the scheme given in Fig. 1.

The organic solvent pulping that underlies the method for obtaining microcrystalline cellulose (MCC) has been described in [1, 18, 19]. Cellulose with the properties as shown in Table 4 has been extracted from corn cobs (Fig. 2, $a$ ) and switchgrass (Fig. 2, $b$ ).

The MCC yield has been established to increase in the case of explosion auto-hydrolysis as pretreatment for obtaining the ultimate product (Table 4). The content of residual lignin in the

\begin{tabular}{|l|c|c|c|}
\hline & $\begin{array}{c}\text { Corn cob } \\
{[16]}\end{array}$ & $\begin{array}{c}\text { Switchgrass } \\
{[17]}\end{array}$ & Rice husk \\
\hline Cellulose & 50.8 & 53.4 & 44.2 \\
Hemicellulose & 1.7 & 3.8 & $1.5 * *$ \\
Hot water soluble & 28.5 & 23.8 & 13.6 \\
Klason lignin & 16.6 & 10.9 & 20.3 \\
Wax and fats & 0.5 & 2.0 & 0.3 \\
Ash & 1.5 & 5.0 & 20.0 \\
Other & 0.4 & 1.1 & 0.1 \\
Total & 100.0 & 100.0 & 100.0 \\
\hline
\end{tabular}

* Conditions of explosion auto-hydrolysis: temperature: $220^{\circ} \mathrm{C}$, run time: 15 min. ** Hemicellulose and proteins totally. 

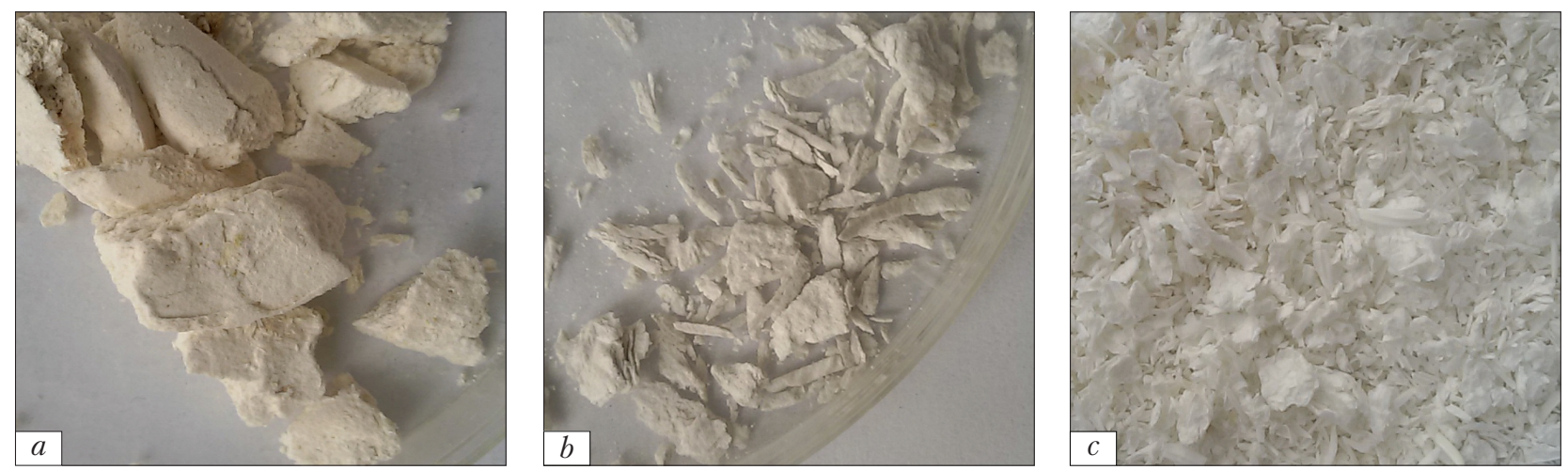

Fig. 2. MCC obtained from corn cobs (a), switchgrass (Panicum virgatum L.) (b), and rice husk (c)

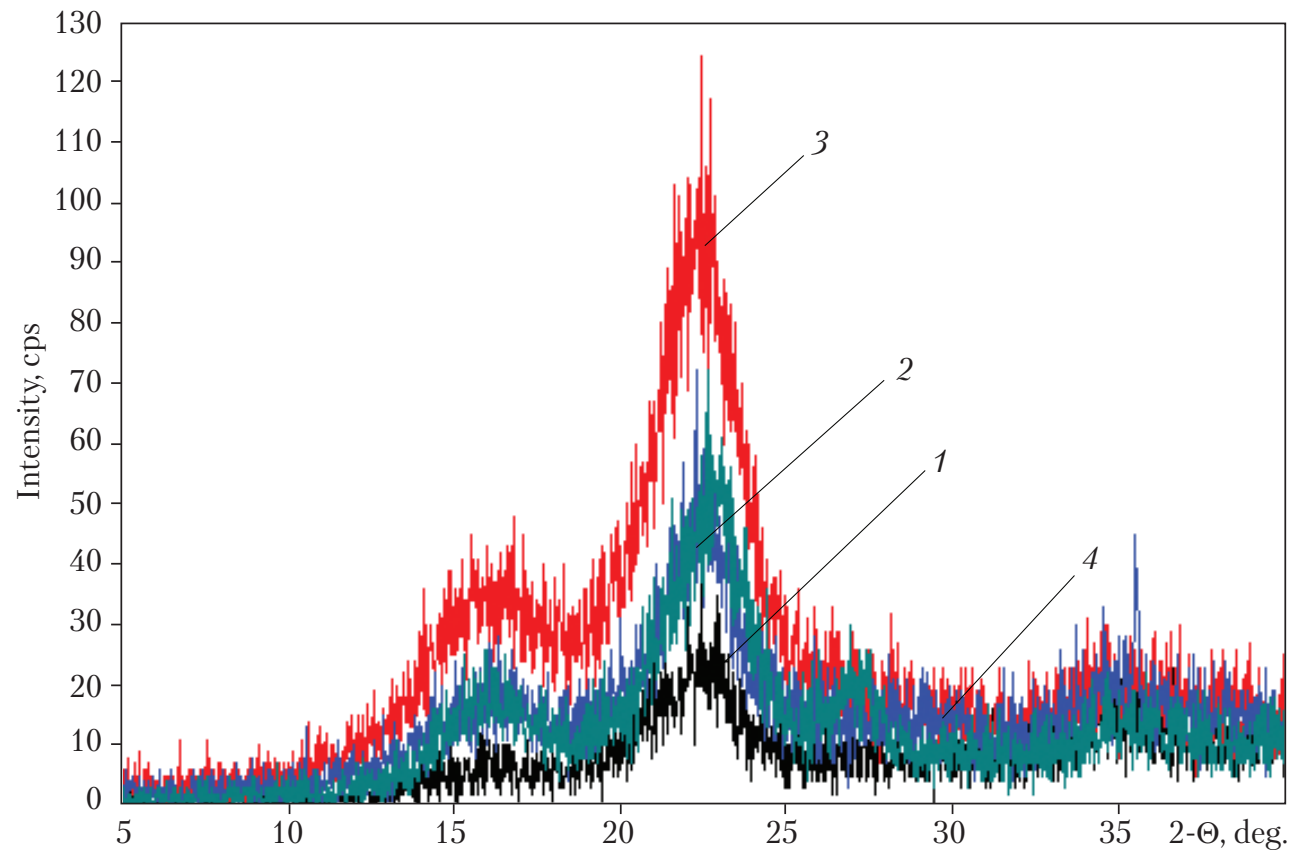

Fig. 3. X-ray diffraction curves of cellulose obtained from corn cobs $(1,2)$ and switchgrass $(3,4)$ in different ways: 1,3 - oxidative hydrolysis method without pretreatment; 2,4 - oxidative hydrolysis after explosion auto-hydrolysis

$0.2-0.3 \mathrm{~mm}$. The scattered intensity was recorded in the mode of step scanning of scintillation detector within the range of angles from 5 to $60^{\circ}$ with a step $0.02^{\circ}$. The diffraction patterns of cellulose samples (Fig. 3) have maximums within the range of angles $2 \theta$ : $14-16^{\circ} ; 22-23^{\circ} ; 34-35^{\circ}$ corresponding to reflection of the planes 10-1, 101; 002; 040 of cellulose lattice, respectively.
The peaks within the range $2 \theta=15-16^{\circ}$ are caused by diffraction of $\mathrm{X}$ rays from the planes 10-1 and 101 of cellulose I lattice. The peak reflex intensity within $2 \theta=22-23^{\circ}$ corresponds to the plane 002 of natural cellulose I lattice. Diffraction pattern of amorphous scattering of cellulose has a typical diffusion character with maximum $2 \theta=18.5-19^{\circ}$. 


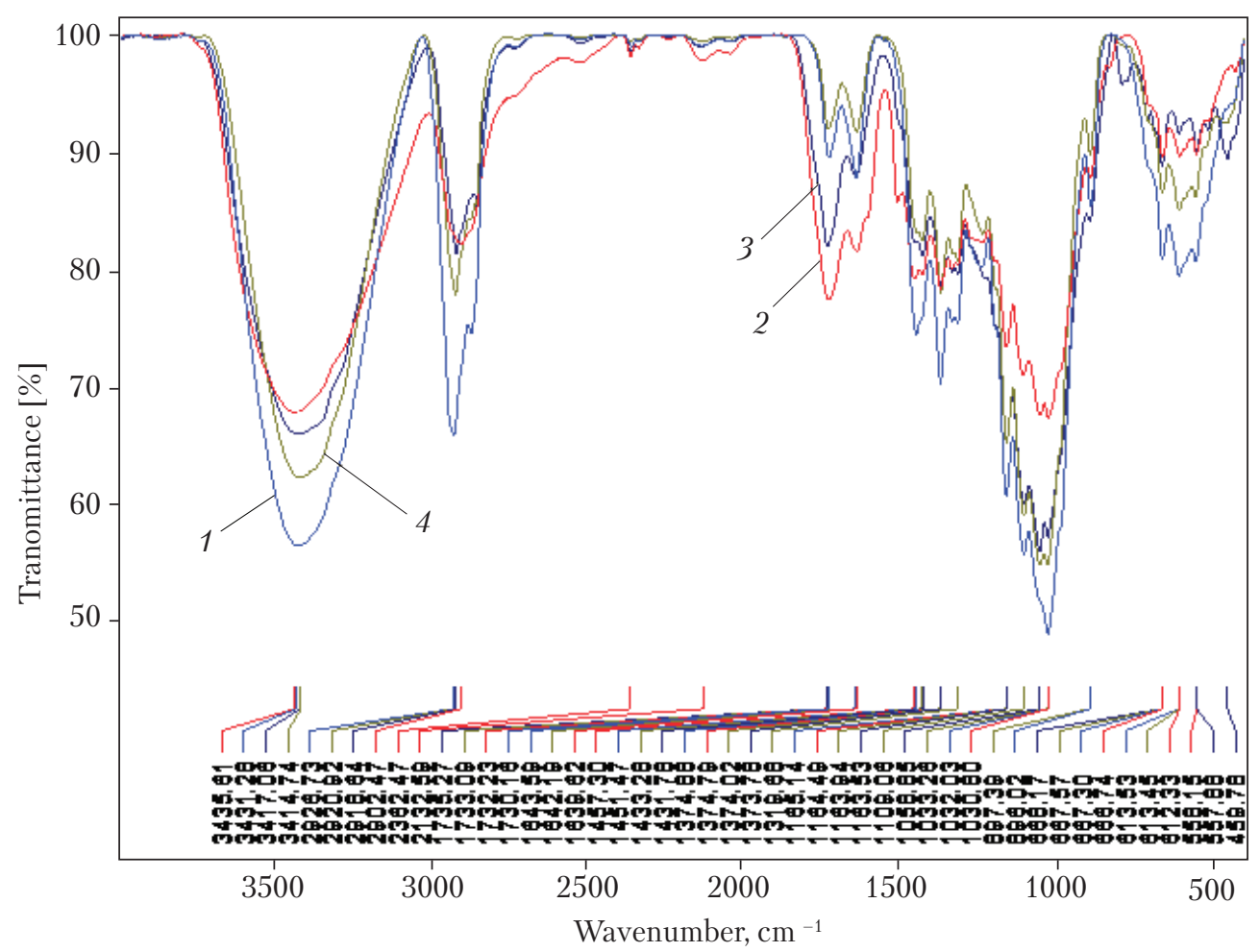

Fig. 4. IR spectra of MCC obtained from corn cobs $(1,2)$ and switchgrass $(3,4)$ in different ways: 1,3 - oxidative hydrolysis method without pretreatment; 2, 4 - oxidative hydrolysis after explosion auto-hydrolysis

To characterize the cellulose structure, the term «crystalline index» (CI) has been introduced and several methods for its determination have been developed [22]. CI measured by Xray study characterizes the share of regularly packed molecules altogether causing the appearance of Bragg reflections on diffraction pattern. The chaotically oriented molecules scatter radi- ation by diffusion mechanism. Basically, the reflex 002 parameters can be an indicator of structural state of cellulose crystalline part in the case of equatorial diffraction. An increase in CI corresponds to a decrease in lignin and amorphous component content. The relative content of crystalline component increases as lingo-hydrocarbon complex is removed [23]. Changes in

Effect of Explosion Auto-Hydrolysis on MCC Yield and Structural Characteristics

Table 4

\begin{tabular}{|l|c|c|c|c|c|c|c|}
\hline \multirow{2}{*}{ Raw material } & \multicolumn{3}{|c|}{ Auto-hydrolysis parameters } & \multicolumn{4}{|c|}{ One-stage delignification of biomass } \\
\cline { 2 - 8 } & $t,{ }^{\circ} \mathrm{C}$ & $P, \mathrm{MPa}$ & $\tau$, min & $\begin{array}{c}\text { Lignin content, } \\
\% \text { wt. }\end{array}$ & MCC yield, \% & \multicolumn{2}{c|}{$\begin{array}{c}\text { CI } \\
\text { Polymerization } \\
\text { degree }\end{array}$} \\
\hline Switchgrass & - & - & - & 1.2 & 40.2 & 0.74 & 577.5 \\
Corn cob & 220 & 3.0 & 15 & 0.9 & 42.5 & 0.81 & 569.0 \\
& - & - & - & 1.1 & 38.7 & 0.77 & 569.0 \\
& & 3.0 & 15 & 1.0 & 49.8 & 0.78 & 560.5 \\
\hline
\end{tabular}




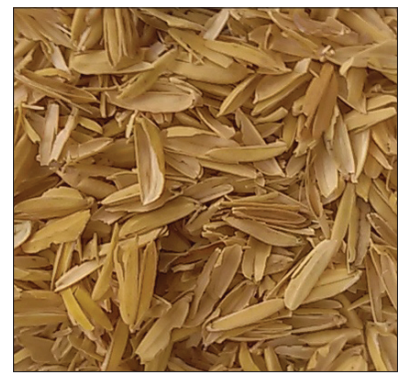

$a$

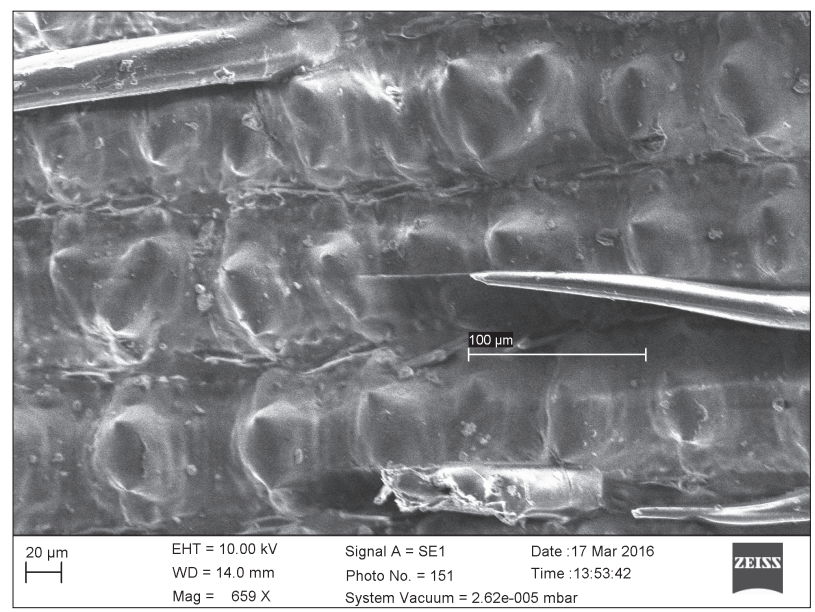

$c$

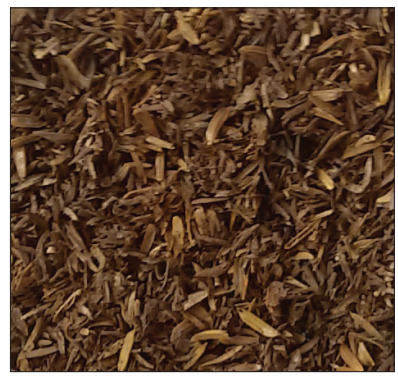

$b$

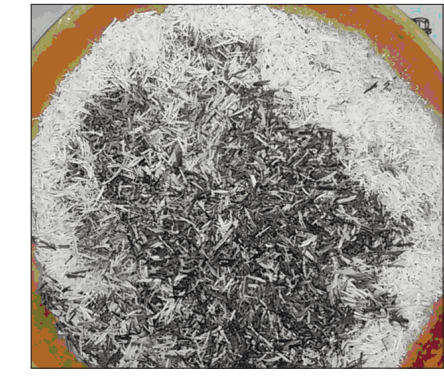

$e$

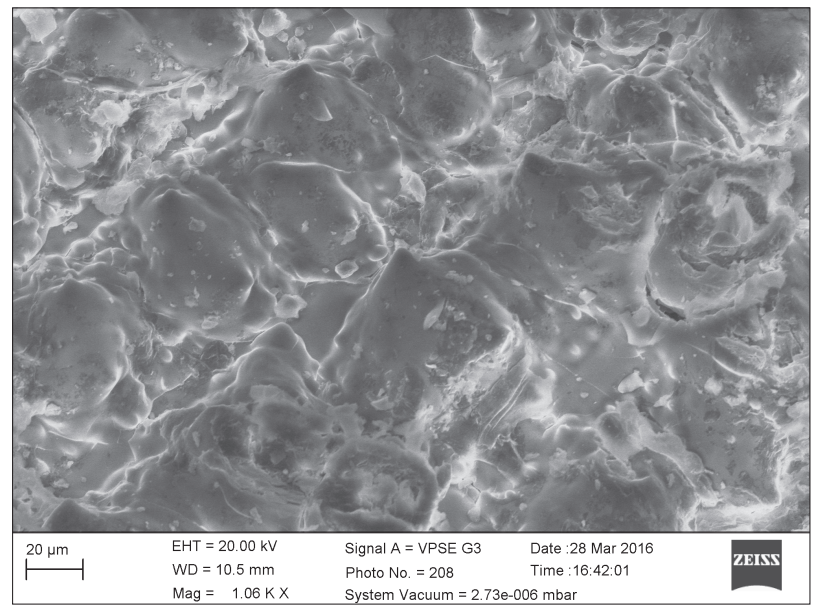

$d$

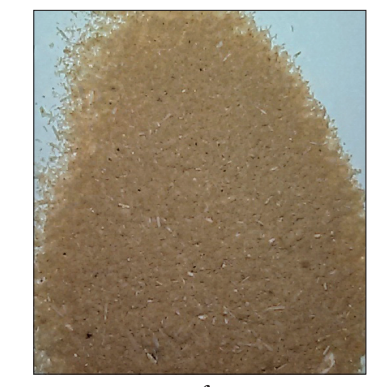

$f$

Fig.5. Macro- (a, b, e, f) and micro-photographs $(c, d)$ of original $(a, c)$ and treated by explosion auto-hydrolysis $(c, d)$ rice husk and its ash $(e, f)$ before $(e)$ and after $(f)$ of thermobaric treatment

CI was calculated by the Jelowicz method modified by the Segal method [23-27].

CI of obtained MCC samples varies within $0.7-$ 0.81 (Table 4 ), which is close to the values for both sulfate and sulfite cellulose from timber (0.650.68) and from cotton (0.8) [24].

The IR spectra of cellulose from corn cobs (Fig. 4, curves 1,2) and switchgrass (Fig. 4, curves 3, 4), as compared with data [28], have typical absorption band (AB) within 3000-3600, 27003000, 1300-1500, 1000-1200 $\mathrm{cm}^{-1}$, which correspond to the stretching vibrations of $-\mathrm{OH}$ and $-\mathrm{CH},-\mathrm{CH}_{2}$ groups and the deformation and stretching vibrations of $\mathrm{CO}$ and $\mathrm{C}-\mathrm{O}-\mathrm{C}$ of cellulose ring, respectively [29]. The adsorbed water manifests itself in absorption band within 1630$1640 \mathrm{~cm}^{-1}$ [30]. The absence of AB at $1511.28 \mathrm{~cm}^{-1}$, which is typical for aromatic skeletal stretching
Ash Residue of Rice Husk after Explosion Auto-Hydrolysis

\begin{tabular}{|c|c|c|c|}
\hline $\begin{array}{c}\text { Chemical } \\
\text { element }\end{array}$ & Content, wt. \% & Compound & $\begin{array}{c}\text { Content, } \\
\text { wt. \% }\end{array}$ \\
\hline $\mathrm{O}$ & $51.966 \pm 0.299$ & & \\
$\mathrm{Mg}$ & $1.348 \pm 0.298$ & $\mathrm{MgO}$ & 2.235 \\
$\mathrm{Si}$ & $0.256 \pm 0.066$ & $\mathrm{Al}_{2} \mathrm{O}_{3}$ & $8 \times 10^{-6}$ \\
$\mathrm{~S}$ & $43.599 \pm 0.267$ & $\mathrm{SiO}_{2}$ & 93.273 \\
$\mathrm{~K}$ & $0.141 \pm 0.004$ & $\mathrm{SO}_{2}$ & 0.283 \\
$\mathrm{Ca}$ & $0.375 \pm 0.033$ & $\mathrm{~K}_{2} \mathrm{O}$ & 0.452 \\
$\mathrm{Fe}$ & $0.640 \pm 0.019$ & $\mathrm{CaO}$ & 0.895 \\
$\mathrm{Fe}$ & $1.590 \pm 0.011$ & $\mathrm{Fe}_{2} \mathrm{O}_{3}$ & 2.274 \\
$\mathrm{Fe}$ & $70 \pm 3 \times 10^{-6}$ & $\mathrm{Ni}_{2} \mathrm{O}_{3}$ & $98 \times 10^{-6}$ \\
$\mathrm{Cu}$ & $122 \pm 4 \times 10^{-6}$ & $\mathrm{CuO}$ & $153 \times 10^{-6}$ \\
$\mathrm{Zn}$ & $0.060 \pm 0.001$ & $\mathrm{ZnO}$ & 0.074 \\
\hline
\end{tabular}




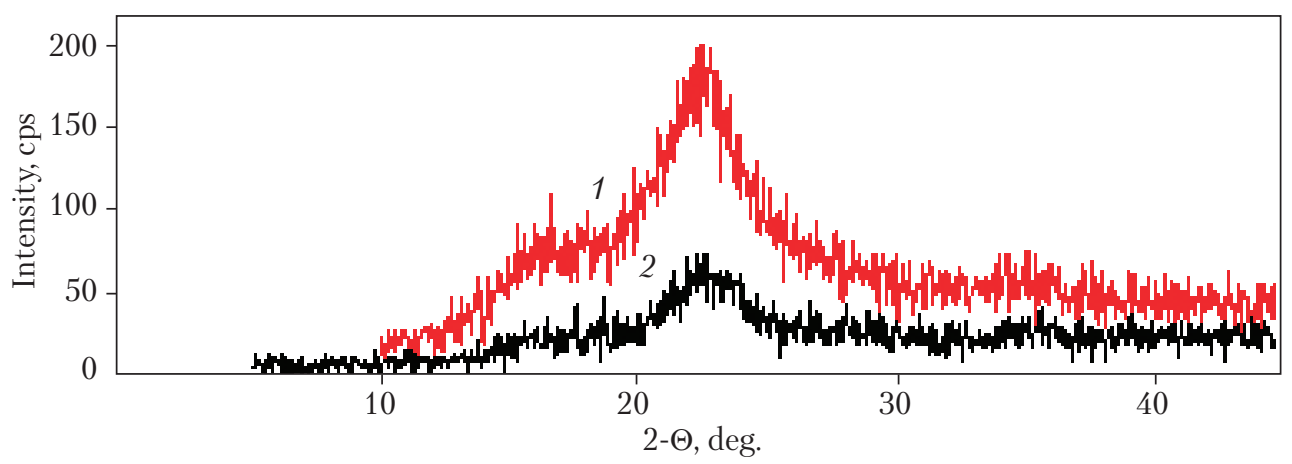

Fig. 6. X-ray diffraction curves of original rice husk (1) and cellulose extracted from it (2)

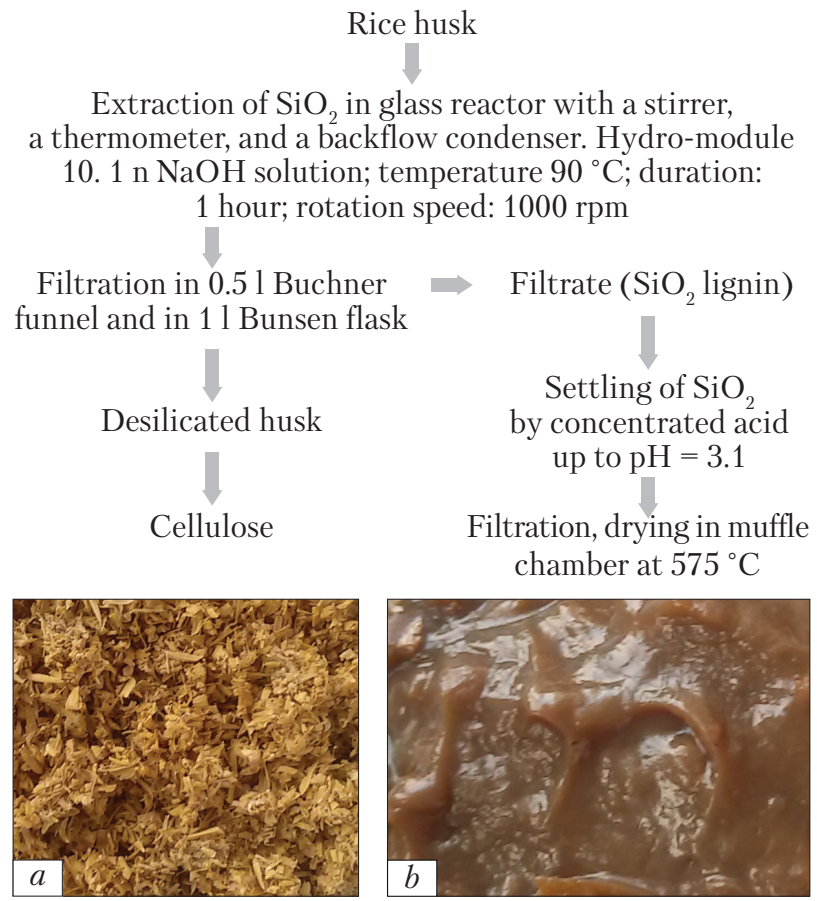

Fig. 7. Scheme of silicon desalinization and photographs of obtained rice husk $(a)$ and filtrate $(b)$

vibrations, confirms a decrease in the lignin content in the products. The absorption band at $900 \mathrm{~cm}^{-1}$ characterizes the asymmetric antiphase vibrations, as well as the vibrations of $\mathrm{C} 1$ atoms and four neighboring atoms of $\beta$-glycoside structures. This band is called the amorphy band [31]. In IR spectra (Fig. 4) of obtained samples, there are no typical AB of phenyl propane units of lignin (1605$\left.1593,1515-1495,1470-1460 \mathrm{~cm}^{-1}\right)$. This testifies to deep oxidative transformations of phenolic structures and effective diffusion of delignification products into the solution under experiment conditions [28].

Rice husk, like the other plants studied as mentioned before, has shown essential morphological changes visible to the naked eye after explosion auto-hydrolysis (Fig. 5, $a, b$ ). The process is accompanied not only with husk fragmenting visible in SEM pictures (obtained with the use of scanning electronic microscope EVO $M A-10$ by Carl Zeiss) (Fig. $5 c, d$ ), but also with destruction of the outer layer of husk epidermis (Fig. 5, $d$ ), which manifests itself as cracks, segregations, and lacunas. In addition, after the explosion auto-hydrolysis, rice husk changes its color (Fig. 5, $b$ ) as a result of change in the composition of main components of lignocellulosic biomass (Tables 1, 2).

Composition of Cellulose Obtained by Organic Solvent Pulping

Table 6

\begin{tabular}{|c|c|c|c|c|c|c|}
\hline \multirow{2}{*}{$\begin{array}{c}\text { Time of organic } \\
\text { solvent pulping, hours }\end{array}$} & $\begin{array}{c}\text { Yield to input } \\
\text { ratio, } \%\end{array}$ & $\begin{array}{c}\text { to theoretical yield } \\
\text { ratio, \% }\end{array}$ & $\begin{array}{c}\text { Polymerization } \\
\text { degree }\end{array}$ & \multicolumn{3}{|c|}{ Product composition, \% } \\
\cline { 5 - 7 } & 57 & 99 & 577.5 & 69 & Cellulose $^{\text {Lignin }}$ & Ash $\left(\mathrm{SiO} \mathrm{O}_{2}\right)$ \\
\hline 4 & 57 & & & $69.98)$ \\
\hline
\end{tabular}


A slight increase in the amount of inorganic components is reported as well (Table 5). An increase in iron content and appearance of nickel and aluminum become noticeable, which is likely explained by corrosion caused by low $\mathrm{pH}$ and steam baric effects. This can influence coloration of rice husk after the explosion auto-hydrolysis (Fig. 5, $f$ ) as compared with the ash of original raw material (Fig. 5,e).

The basic properties of cellulose obtained from rice husk by the organic solvent pulping method (Fig. 2,c), are given in Table 6.

Table 6 shows that in the case of organic solvent pulping, rice husk is almost fully delignified. Due to this, bleached cellulose that for the third part consists of inorganic component, namely, of silicon dioxide, has been obtained. This silicon dioxide manifests itself in X-ray structure studies of obtained material (Fig. 6).

The diffraction pattern (Fig. 6, curve 2) of extracted cellulose shows that it has an amorphous structure and contains amorphous silicon dioxide, which is confirmed by a characteristic peak within $2 \theta=22.5^{\circ}$ observed in the diffraction pattern of original raw material (Fig. 6, curve 1) [32].

Hence, the use of rice husk for obtaining microcrystalline cellulose is not feasible, since the ultimate product is highly amorphous because of a large share (about 30\% (wt.)) of inorganic component, silicon dioxide. Therefore, for obtaining cellulose it is necessary firstly to separate this substance from rice husk. The $\mathrm{SiO}_{2}$ separation is made in accordance with the scheme shown in Fig. 7.

The rice husk obtained in this way (Fig. 7,1 ) contains $62.63 \%$ cellulose (wt., absolutely dry matter), 16.71\% lignin (wt., absolutely dry matter), and $1.6 \%$ ash residue (wt., absolutely dry matter), while the content of ash residue in the original raw material reached 18\% (wt. absolutely dry matter) (Table 1).

A decrease in the content of last two components as compared with cellulose means that as a result of alkali treatment both silicon dioxide and lignin are removed from the raw material. This can be confirmed by the very appearance of deposition

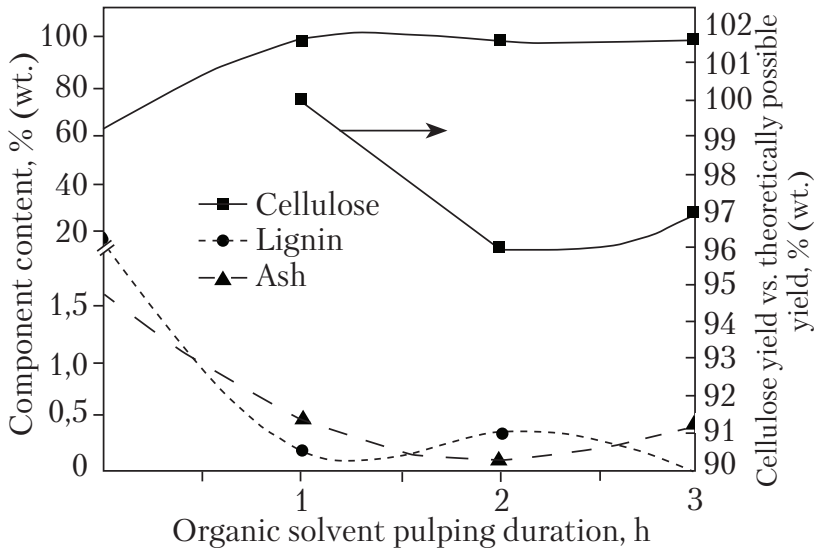

Fig. 8. Dependence of changes in the content of main components of rice husk on treatment time

obtained after desalinization and treatment with acid (Fig. 7, 2). Its ash content, 10\% (wt., absolutely dry matter), means that it contains not only inorganic (Table 7), but also other components.

Table 7

Ash Content in Filtrate

\begin{tabular}{|c|r|c|c|}
\hline $\begin{array}{c}\text { Chemical } \\
\text { element }\end{array}$ & Content, wt. \% & Compound & $\begin{array}{c}\text { Content, } \\
\text { wt. \% }\end{array}$ \\
\hline $\mathrm{O}$ & $47.858 \pm 1.032$ & & \\
$\mathrm{Mg}$ & $1.153 \pm 0.289$ & $\mathrm{MgO}$ & 1.912 \\
$\mathrm{Si}$ & $40.773 \pm 0.810$ & $\mathrm{SiO}_{2}$ & 87.227 \\
$\mathrm{~S}$ & $0.394 \pm 0.011$ & $\mathrm{SO}_{2}$ & 0.787 \\
$\mathrm{Cl}$ & $8.825 \pm 0.177$ & $\mathrm{Cl}_{2}$ & 8.825 \\
$\mathrm{~K}$ & $0.769 \pm 0.044$ & $\mathrm{~K}_{2} \mathrm{O}$ & 0.926 \\
$\mathrm{Fe}$ & $0.202 \pm 0.005$ & $\mathrm{Fe}_{2} \mathrm{O}_{3}$ & 0.288 \\
$\mathrm{Ni}$ & $19 \pm 2 \times 10^{-6}$ & $\mathrm{Ni}_{2} \mathrm{O}_{3}$ & $27 \times 10^{-6}$ \\
$\mathrm{Cu}$ & $107 \pm 4 \times 10^{-6}$ & $\mathrm{CuO}^{-6}$ & $134 \times 10^{-6}$ \\
$\mathrm{Zn}$ & $53 \pm 2 \times 10^{-6}$ & $\mathrm{ZnO}$ & $66 \times 10^{-6}$ \\
\hline
\end{tabular}

Table 8

Effect of Time of Husk Treatment without Silicon Oxide on MCC Yield and Structural Properties

\begin{tabular}{|c|c|c|c|}
\hline \multirow{2}{*}{$\begin{array}{c}\text { Time of organic } \\
\text { solvent pulping, } \\
\text { hours }\end{array}$} & \multicolumn{3}{|c|}{ One-stage delignification of biomass } \\
\cline { 2 - 4 } & MCC yield, \% & CI & $\begin{array}{c}\text { Polymerization } \\
\text { degree }\end{array}$ \\
\hline 1 & 62.7 & 0.77 & 560.5 \\
2 & 60 & 0.73 & 565.0 \\
3 & 61 & 0.79 & 569.0 \\
\hline
\end{tabular}




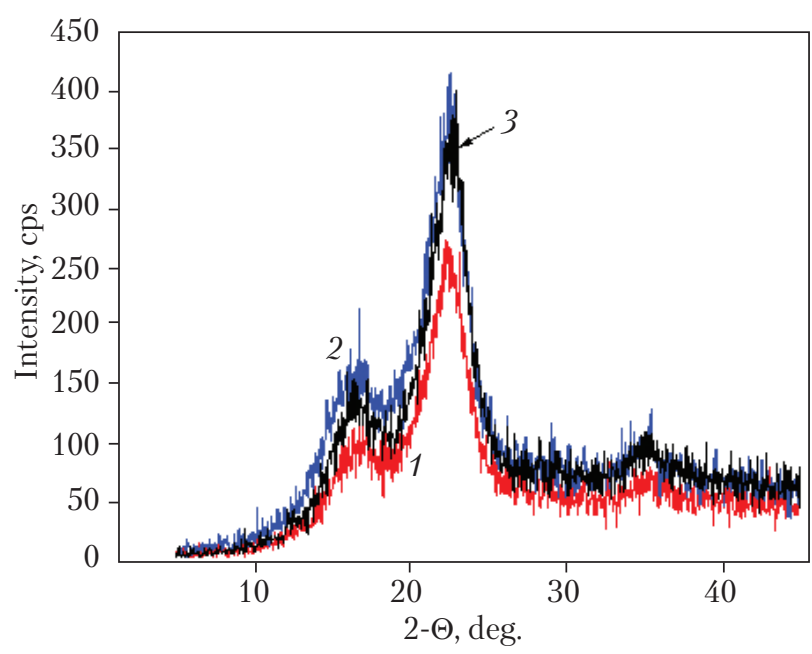

Fig. 9. X-ray diffraction curves of cellulose obtained from silicon-free rice husk depending on treatment time: $1-1$ hour; $2-2$ hours; $3-3$ hours

Since, as mentioned before, the alkaline leaching of silicon dioxide results in partial delignification and removal of inorganic components, the possibility of speeding up the obtainment of microcrystalline cellulose at the expense of reduction in time of organic solvent pulping has been studied. Cellulose treatment time has been established to influence not only the composition of cellulose obtained, but also its yield (Fig. 8, Table 8). In 1 hour after the treatment, a rapid decrease in in the content of lignin and inorganic compo-

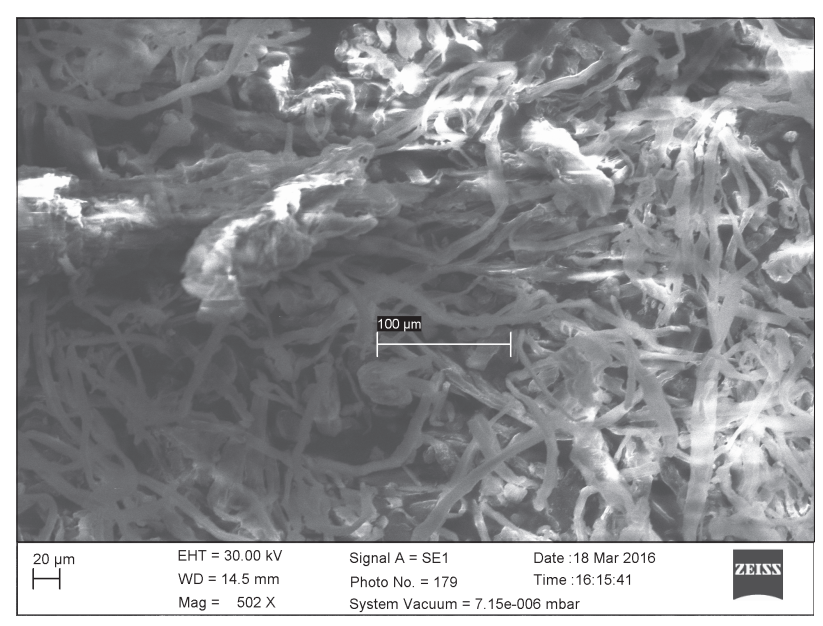
$a$ nents. Further treatment does not result in any significant changes (Fig. 8). The polymerization degree of cellulose obtained has been determined (Table 8). It is as much as twice higher as compared with the required value for microcrystalline cellulose of vegetable origin (200-300) [33]. However, this is not the only criterion of cellulose crystallinity, therefore additional physical and chemical studies have been done.

The supramolecular structure of MCC obtained from rice husk has been established using the method of X-ray diffraction analysis (Fig. 9).

The CI of MCC obtained samples is estimated as $0.73-0.79$ (Table 8), which, as mentioned above, is in good agreement with the data for commercial samples [24].

Using SEM the morphological properties of fibers of obtained cellulose (Fig. 10) have been studied. The treatment time has been established to change the structure of fibers inessentially. Their average length is about $200-300 \mu \mathrm{m}$, which corresponds to the requirements for MCC fibers (up to $400 \mu \mathrm{m}$ ) [33].

In this research, a cellulose product has been obtained from rice husk pretreated for removal of silicon dioxide using a simplified method. The product may be referred to microcrystalline cellulose by two (CI and fiber length) of three parameters (except for polymerization degree).

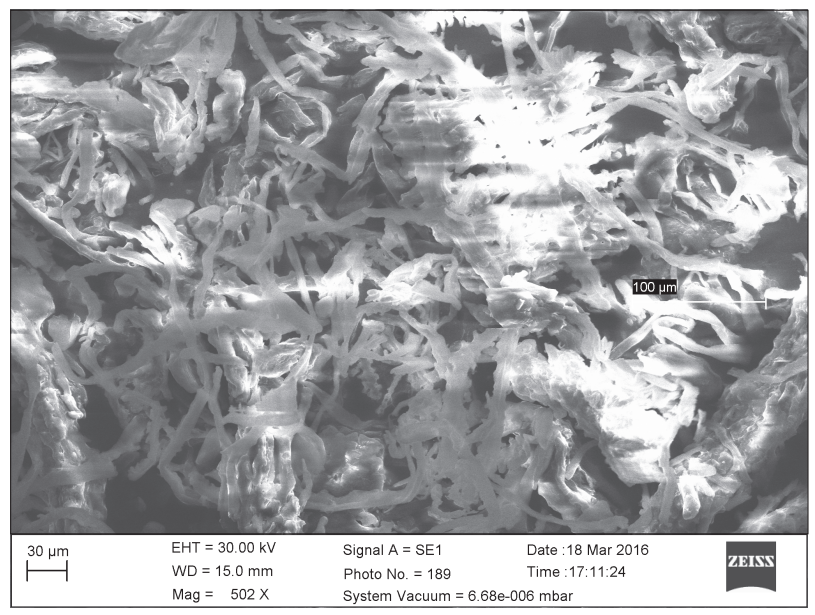

$b$

Fig. 10. SEM images of MCC extracted from silicon-free rice husk with different treatment time: $1-1$ hour; $2-3$ hour 


\begin{tabular}{|c|c|c|c|c|}
\hline \multicolumn{5}{|c|}{$\begin{array}{l}\text { Yield of Aldehyde Alcohols from Oxidation } \\
\text { of Lignins of Various Origins by Molecular Oxygen }\end{array}$} \\
\hline \multirow[b]{2}{*}{$\begin{array}{c}\text { Raw } \\
\text { material }\end{array}$} & \multicolumn{2}{|c|}{ Conditions } & \multicolumn{2}{|c|}{ Yield, \% (wt., lignin) } \\
\hline & $\begin{array}{l}\text { Tempera- } \\
\text { ture, }{ }^{\circ} \mathrm{C}\end{array}$ & $\begin{array}{c}\text { Partial } \\
\text { pressure } \\
\mathrm{O}_{2}, \mathrm{MPa}\end{array}$ & Vanillin & $\begin{array}{l}\text { 4-hydroxy- } \\
\text { benzalde- } \\
\text { hyde }\end{array}$ \\
\hline $\begin{array}{l}\text { Hydrolytic } \\
\text { lignin }\end{array}$ & 170 & 0.9 & 2.84 & 0.05 \\
\hline Switchgrass & & $\begin{array}{l}0.3 \\
0.9\end{array}$ & $\begin{array}{l}0.48 \\
3.25\end{array}$ & $\begin{array}{l}0.45 \\
0.03\end{array}$ \\
\hline Corn cobs & & 0.3 & 1.05 & 1.46 \\
\hline & & 0.9 & 4.84 & 0.36 \\
\hline Rice husk & & 0.3 & 3.59 & 0.99 \\
\hline & & 0.9 & 10.68 & 0.003 \\
\hline
\end{tabular}

Composition of Inorganic Part Extracted from Ash Residue of Rice Husk

\begin{tabular}{|l|c|c|}
\hline \multicolumn{1}{|c|}{ Formula } & Content, wt. \% & Content, wt. \% \\
\hline $\mathrm{SiO}_{2}$ & 99.994 & 99.994 \\
$\mathrm{Fe}_{2} \mathrm{O}_{3}$ & $56 \times 10^{-6}$ & $50 \times 10^{-6}$ \\
$\mathrm{ZnO}$ & - & $5 \times 10^{-6}$ \\
\hline
\end{tabular}

According to literature data, the oxidation of lignins of herbal plants is accompanied with the creation of the most hard-to-separate blend of the three aldehydes - vanillin, syringaldehyde, and para-hydroxybenzaldehyde, with a small total yield (3-24\%) [34]. The effect of oxidation on lignin as original lignin-containing matter has been studied on corn cobs, switchgrass, rice husk, and hydrolytic lignin using the method described in $[35,36]$. The obtained results are given in Table 9 .

The effect of molecular oxygen on the yield of vanillin and 4-hydroxybenzaldehyde has been proven. There have been no data on the effect of oxidizer concentration on the formation of the latter. Table 9 shows, as partial pressure of oxygen increases trice, the yield of vanillin grows 3-6 times, depending on lignin-containing material. This is explained by different group composi- tion of lignins, which is in good agreement with literature data [35, 36]. At the same time, the yield of 4-hydroxybenzaldehyde drops, which likely is a result of higher selectivity of vanillin formation as partial pressure of molecular oxygen increases. Unfortunately, for the time being, there are no data on the obtainment of vanillin from plant lignocellulosic biomass characterized in Table 9 by reagent methods. The yield of vanillin for oxidation of aspen by molecular oxygen at a partial pressure of $0.2 \mathrm{MPa}$ for $60 \mathrm{~min}$ amounts to $2.66 \%$ (per lignin) [37], which is close to the yield from the oxidation of rice husk (Table 9 ).

High-purity silicon dioxide having the properties shown in Table 10 has been obtained from inorganic part of rice husk the composition of which is given in Table 2, using the method described in [38]. The XRD analysis has shown that the obtained powdered silicon dioxide consists of $100 \%$ amorphous phase.

\section{CONCLUSIONS}

A method for obtaining cellulose from nonwoody raw materials (corn cobs, switchgrass, rice husk) by organic solvent pulping has been studied. The effect of pretreatment of lignocellulosic biomass on physical and chemical properties of obtained cellulose has been established. Using the method of four-hour organic solvent pulping a cellulose with a crystallinity index of 0.74 and 0.77 , respectively, and a polymerization degree of 569.0 and 577.5, respectively, has been obtained from corn cobs and switchgrass. The yield is 90 and $86 \%$ of the possible in theory, respectively. The treatment of raw plant material in auto-hydrolysis conditions has been shown to enable dividing the original compact strong structure into individual components that after further treatment give ultimate products with a yield significantly higher than in the case of the classical treatment. For cellulose, the total conversion grows by $6-18 \%$ with a high CI of 0.81 (switchgrass). In the case of alkali treatment of rice husk, the inorganic component is extracted, with its share dropping from 18 to $1.6 \%$ (wt., absolutely dry 
matter). Also, partial delignification has been observed as lignin content decreases from 20.2 to $16.7 \%$ (wt., absolutely dry matter). At the same time, cellulose content increases from about 40 to 63\% (wt., absolutely dry matter), which enables obtaining microcrystalline cellulose with a yield of $100 \%$ of the possible in theory, a crystallinity index of 0.77 , a polymerization degree of 560.5 , and a purity of $99.3 \%$, (lignin content is less than $0.2 \%$ (wt., absolutely dry matter); ash content is less than $0.5 \%$ (wt., absolutely dry matter)) after 1 hour of organic solvent pulping. The aldehyde yield has been studied for various types of lignocellulosic biomass. The highest yield of vanillin has been shown to be reached by rice husk oxidation with air oxygen at an oxidizer partial pressure of $0.9 \mathrm{MPa}$. The inverse dependence of 4-hydroxybenzaldehyde yield on the amount of oxidizer has been established. High-purity silicon dioxide has been obtained. Its content makes up, at least, $99.99 \%$, which has been confirmed by various advanced methods for physical and chemical analysis.

The research has been financially supported by the NAS of Ukraine within the framework of $R \mathcal{E} \mathcal{D} D$ project «The Development of Technological Solution for Integrated Treatment of Agrowastes》 (contract No. 8/1i-16) in 2016.

\section{REFERENCES}

1. Kuznetsov, B.N., Sharypov, V.I., Grishechko, L.I., Celzard, A. (2013). Integrated catalytic process for obtaining liquid fuels from renewable lignocellulosic biomass. Kinetics and Catalysis. 54(3). 344-352 [in Russian].

2. Ikawo O.E. (2013). Conversion of agrowastes to bioproducts. Lagos. 56 p.

3. Supitcha Rungrodnimitchai. Wachira Phokhanusai. Natthapong Sungkhaho. (2009). Preparation of Silica Gel from Rice Husk Ash Using Microwave Heating. Journal of Metals. Materials and Minerals. 19(2). 45-50.

4. Zemnukhova, L.A., Budaeva, V.V., Fedorishcheva, G.A., Kaydalova, T.I., Kurilenko, L.N., Shkorina, E.D., Ilysov, S.G. (2009). Inorganic components of straw and hull of an oats. Himija rastitel'nogo syr'ja (Chemistry of plant rawe material). 1. 147-152 [in Russian].

5. Vurasko, A.V., Driker, B.N., Mozyreva, E.A., Zemnukhova, L.A., Galimova, A.R., Gulemina, N.N. (2006). Resursosberegayushchaya tekhnologiya polucheniya tsellyuloznykh materialov pri pererabotke otkhodov sel'skokhozyaystvennykh kul'tur. Himija rastitel'nogo syr'ja (Chemistry of plant raw material). 4. 5-10 [in Russian].

6. Jose James, M. Subba Rao. (1986). Silica from rice husk through thermal decomposition. Thermochimica Acta. 97. 329-336.

7. Pat. GB 1508825. Refratech Albert Gmbh. A method of production low-carbon. white husk ash.

8. Soroka, P.I., Tertyshnyj, O.A., Smirnova, E.S., Gridneva, T.V. (2006). Poluchenie soedineniy kremniya iz othodov risovogo proizvodstva. Naukovi pratsi Odes'koji nats. akademii harchov. tekhnologiy. 2(28). 4-10 [in Russian].

9. Matkovsky, P., Yarulin, R. (2011). Silica in human world. The Chemical Journal. 1. 36-39.

10. Gridneva, T.V., Soroka, P.I., Tertyshnyj, O.A., Ryabik, P.V., Smirnova, E.S. (2010). Poluchenie dioksida kremniya iz risovoy sheluhi. Ekologichni aspekty ta resursozberigayuchi technologii. 3. 100-102 [in Russian].

11. Koz'mina, E.P. (ed.). (1976). Ris i ego kachestvo. Moskva: Kolos [in Russian].

12. Sergienko, V.I., Zemnukhova, L.A., Egorov, A.G., Shkorna, E.D., Vassilynk, N.S. (2004). Renewable sources of chemical raw materials\& complex processing of the wastes of rice and buckwheal Russian chem.j. (of Russian chem. Society named after D.I. Mendeleev). XLVII(3). 116-124 [in Russian].

13. Tsoi, E.A. (2015). Silicon containing material from rice straw: compound. structure and properties. PhD (Ecol.) Vladivostok [in Russian].

14. Haoran Chen. (2013). Biogenic silica nanoparticles derived from rice husk biomass and their applications. A dissertation submitted to the Graduate Council of Texas State University in partial fulfillment of the requirements for the degree of Doctor of Philosophy with a Major in Materials Science. Engineering. and Commercialization. 197 p.

15. Andrievskii, R.A. (1995). Silicon nitride: synthesis and properties. Uspekhi Khimii. 64(4). 311-329 [in Russian].

16. Kamenskyh, D.S., Tkachenko, T.V., Yevdokymenko, V.O., Kashkovskiy, V.I. (2015). Explosive autohydrolysis of pentosan-containing raw material. Catalysis and Petrochemistry. 24. 90-95 [in Ukrainian].

17. Tigunova, O.O., Beiko, N.E., Kamenskyh, D.S., Tkachenko, T.V., Yevdokymenko, V.O., Kashkovskiy, V.I., Shulga, S. M. (2016). Lignocellulosic Biomass after Explosive Autohydrolysis as Substrate for Butanol. Biotechnologia Acta. 9(4). 28 -34. 
18. Kuznetsov, B.N., Taraban'ko, V.E., Kuznetsova, S.A. (2008). New catalytic methods for obtaining cellulose and other chemical products from vegetable biomass. Kinetics and Catalysis. 49(4). 517-526.

19. Kuznetsov, B.N., Chesnokov, N.V., Garyntseva, N.V., Yatsenkova, O.V. (2013). Integrated catalytic processing of aspen wood into liquid and solid biofuels. J. Siber. Fed. Univ. Chem.. 3. 286-298 [in Russian].

20. GOST 26177-84. Fodder. mixed feeds. Method for determination of lignin. 3 p. [in Russian].

21. Obolenskaya, A.V., El'nitskaya, Z.P., Leonovich, A.A. (1991). Laboratornye raboty po khimii drevesiny $i$ tsellyulozy [Laboratory Works on Wood and Cellulose Chemistry]. Moskva [in Russian].

22. Sunkyu Park, John O. Baker, Michael E. Himmel, Philip A. Parilla and David K. Johnson. (2010). Cellulose crystallinity index: measurement techniques and their impact on interpreting cellulase performance. Biotechnology for Biofuels. 3(10). URL: http://www.biotechnologyforbiofuels.com/content/3/1/10 (Last accessed: 01.11.2017).

23. Baryshnikov, S.V., Sharypov, V.I., Zhyzhaev, A.M., Beregovtsova, N.G., Kuznetsov, B.N. (2012). Variation a Structural Order of Aspen Wood During its Mechanochemical Activation and Hydrilysisa.J. Siber. Fed. Univ. Chem.. 2(3). 120-127 [in Russian].

24. Danilov, V.G., Yatsenkova, O.V., Kuznetsov, B.N. (2012. October). Obtaining of the microcrystalline cellulose from steam-explotion aspen wood. Lesnoy i himichesky kompleksy - problemy i resheniya. Sbornyk statey po materialam Vserossiyskogoy nauchno-prakticheskoy konferenchii. 80-84 [in Russian].

25. Golyazimova, O.V., Politov, A.A., Lomovsky, O.I. (2009). Intensification of raw material grinding with chemical treatment. Himija rastitel'nogo syr'ja (Chemistry of plant raw material). 2. 53-57 [in Russian].

26. Shevchuk, O.M., Zil'bergleit, M.A., Shishakov, E.P. (2013). The X-ray analysis of sulfate cellulose from different manufacturers. Himija rastitel'nogo syr'ja (Chemistry of plant raw material). 3. 43-47 [in Russian].

27. Nicoleta Terinte, Roger Ibbett, Kurt Christian Schuster. (2011). Overviewon native cellulose and microcrystalline cellulose. I Structure studied by X-ray diffraction (WAXD): comparison betweenmeasurement techniques. Lenzinger Berichte. 89. 118-131.

28. Kushnir, E.J., Autlov, S.A., Bazarnova, N.G. (2014). Preparation of microcrystalline cellulose directly from wood under microwave irradiation. Himija rastitel'nogo syr'ja (Chemistry of plant raw material). 2. 41 -50 [in Russian].

29. Bazarnova, N.G., Karpova, E.V., Katrakov, I.B., Markin, V.I., Mikushina, I.V., Ol’hov, J.A., Khudenko, S.V. (2002). Analysis of wood and it's derivative. Barnaul [in Russian].

30. Kuznetsov, B.N., Sudakova, I.G., Garyntseva, N.V., Ivanchenko, N.M. (2013). Abies wood delignification by hydrogen peroxide at mild conditions in the presence of sulfuric acid catalyst. J. Siber. Fed. Univ. Chem.. 4(6). 361-371 [in Russian].

31. Levdansky, V.A., Levdansky, A.V., Kuznetsov, B.N. (2014). Ecology safe method of obtaining from firwood the cellulosic product with high content of alfa-cellulose. Himija rastitel'nogo syrja (Chemistry of plant raw material). 2. 35-40 [in Russian]

32. Xinsheng Wang, Zhenlin Lu. Lei Jia, Jiangxian Chen. (2016). Physical Properties and Pyrolysis Characteristics of Rice Husks in Different Atmosphere Results in Physics. 6. 866-868.

33. Autlov, S.A., Bazarnova, N.G., Kushnir, E.J. (2013). Preparation of microcrystalline cellulose directly from wood under microwave irradiation. Himija rastitel'nogo syr'ja (Chemistry of plant raw material). 3. 33-41 [in Russian].

34. Taraban'ko, B.E., Koropachinskaya, N.B., Kudryashev, A.B., Pervyshina, E.N., Kuznetsov, B.N., Polyakov, S.V., Zolotuhin, V.N. (1998). Investigation of wheat straw's treatment to aromatic aldehyde and levulinic acid. Himija rastitel'nogo syr'ja (Chemistry of plant raw material). 3. 59-64 [in Russian].

35. Gogotov, A.F., Rybal'chenko, N.A., Makovskaya, T.I., Babkin, V.A. (1996). Catalytical nitrobenzene oxidation of lignins. Russian Chemical Bulletin. 45(12). 2854-2857.

36. Taraban'ko, V.E., Koropatchinskaya, N.V., Kudryashev, A.V., Kuznetsov, B.N. (1995). Influence of lignin origin on the efficiency of the catalytic oxidation of lignin into vanillin and syringaldehyde. Russian Chemical Bulletin. 44(2). 367-371.

37. Kaygorodov, K.L., Taraban'ko, V.E., Chelbina, Yu.V., Iljin, A.A., Koropachinskaya, N.V. (2012. November). Pererabotka othodov proizvodstva biotopliva v vanalin I drugie produkty tonkogo organicheskogo sinteza. Mater. vser. konf. «Khimiya i Khimicheskaya technologiya: dostigeniya i perspektivy». Kemerovo [in Russian].

38. Patent application for invention of Ukraine № a 201706242 Yevdokymenko V.O., Kamenskyh D.S., Kashkovskiy V.I., Vakhrin V.V. Method of obtaining of the amorphous silicon dioxide from rice husk [in Ukrainian].

Received 20.12.17 


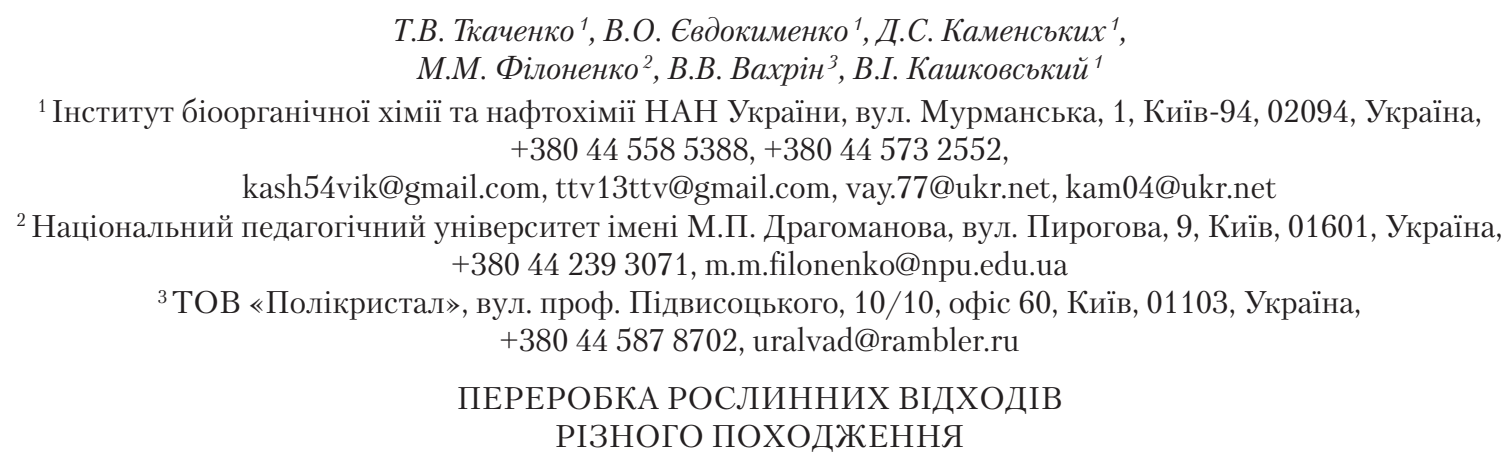

Вступ. Біомаса переважно застосовується як енергетичне джерело, тоді як вона є цінною хімічною сировиною. На сьогодні виділено 20 базових сполук, які можна отримати із рослинної біомаси та яких достатньо для виготовлення широкого асортименту продукції хімічної промисловості.

Проблематика. Незважаючи на значний потенціал рослинних відходів для промисловості, в Україні роботам у цьому напрямку приділяється недостатньо уваги.

Мета. Створення ефективного технологічного рішення, яке забезпечить комплексну практично безвідходну переробку відходів рослинного походження з одержанням ліквідних продуктів.

Матеріали й методи. В дослідженні використано метод органо-сольветної варки, метод вибухового автогідролізу, гетерогенного каталізу, низку аналітичних методів (технічний, елементний, структурний аналіз).

Результати. Показано, що обробка рослинної сировини в умовах автогідролізу дозволяє зруйнувати вихідну компактну, міцну структуру та розкласти ії на індивідуальні складові. Для мікрокристалічної целюлози (МКЦ) відбувається зростання загальної конверсії на $6-18$ \% із високим індексом кристалічності (ІК) - 0,81. Встановлено, що при лужній обробці рисової лузги спостерігається «екстракція» неорганічної складової та зменшення її вмісту, а також часткова делігніфікація з одночасним збільшенням вмісту целюлози. Методом органо-сольветної варки лузги, з якої попередньо видалено кремнієві сполуки, виділено максимальну кількість МКЦ (100% від теоретично можливого), з ІК 0,77 , ступенем полімеризації 560,5 та чистотою 99,3 \%. Разом з тим одержано зразок діоксиду кремнію, з вмістом $\mathrm{SiO}_{2}$ не менше $99,99 \%$.

Висновки. Наведено спосіб одержання целюлози з відходів рослинництва методом органо-сольвентної варки та встановлено вплив процесу попередньої обробки лігноцелюлозної біомаси на фізико-хімічні характеристики одержаної целюлози.

Ключові слова: вибуховий автогідроліз, целюлоза, лігнін, мікрокристалічна целюлоза, діоксид кремнію.

\author{
Т.В. Ткаченко ${ }^{1}$, В.А. Евдокименко ${ }^{1}$, Д.С. Каменских ${ }^{1}$, \\ М.Н. Филоненко ${ }^{2}$ В.В. Вахрин ${ }^{3}$, В.И. Кашковский ${ }^{1}$ \\ ${ }^{1}$ Институт биоорганической химии и нефтехимии НАН Украины, \\ ул. Мурманская, 1, Киев-94, 02094, Украина, \\ +380445585388, +380445732552, \\ kash54vik@gmail.com,ttv13ttv@gmail.com, vay.77@ukr.net,kam04@ukr.net \\ ${ }^{2}$ Национальный педагогический университет имени М.П. Драгоманова, \\ ул. Пирогова, 9, Киев, 01601, Украина, \\ +380 44239 3071, m.m.filonenko@npu.edu.ua \\ ${ }^{3} \mathrm{OOO}$ «Поликристал», ул. проф. Подвысоцкого, 10/10, офис 60, Киев, 01103, Украина, \\ +380445878702, uralvad@rambler.ru
}

\title{
ПЕРЕРАБОТКА РАСТИТЕЛЬНЫХ ОТХОДОВ РАЗЛИЧНОГО ПРОИСХОЖДЕНИЯ
}

Введение. Биомасса в большинстве случаев используется как энергетический источник, тогда как она является ценным химическим сырьем. На сегодня выделено 20 базовых соединений, полученных из растительного сырья и которых достаточно для изготовления большого ассортимента химической продукции.

Проблематика. Не смотря на существенный потенциал растительных отходов для промышленности, в Украине работам в этом направлении уделяется недостаточно внимания. 
Цель. Создание эффективного технологического решения, которое обеспечит комплексную практически безотходную переработку отходов растительного происхождения с получением ликвидных продуктов.

Материалы и методы. В исследовании использован метод органо-сольвентной варки, метод взрывного автогидролиза, гетерогенного катализа, ряд аналитических методов (технический, элементный, структурный анализ).

Результаты. Показано, что обработка растительного сырья в условиях автогидролиза позволяет разрушить исходную компактную, крепкую структуру и разделить ее на индивидуальные составляющие. Для микрокристаллической целлюлозы (МКЦ) происходит увеличение общей конверсии на 6-18 \% с высоким индексом кристалличности (ИК) - 0,81. Установлено, что при щелочной обработке рисовой шелухи наблюдается «экстракция» неорганической составляющей и уменьшение ее содержания, а также частичная делигнификация с одновременным увеличением содержания целлюлозы. Методом органо-сольветной варки из предварительно очищенной от соединений кремния шелухи выделено максимальное количество МКЦ (100 \% от теоретически возможного), с ИК 0,77, степенью полимеризации 560,5 и чистотой 99,3 \%. Вместе с тем, получено образцы диоксида кремния с содержанием $\mathrm{SiO}_{2}$ не меньше 99,99 .

Выводы. Приведен способ получения целлюлозы из растительных отходов методом органо-сольвентной варки и установлено влияние процесса предварительной обработки лигноцеллюлозной биомассы на физико-химические характеристики полученной целлюлозы.

Ключевые слова: взрывной автогидролиз, целлюлоза, лигнин, микрокристаллическая целлюлоза, диоксид кремния. 